Zdravko MLINAR

\title{
Inovativnost $v$ stanovanjski gradnji in vloga stanovanjskega sklada: od stanovanja k vseživljenjskemu okolju
}

\section{Innovativeness in housing construction and the role of the Housing Fund: From residence to an integral living environment}

\begin{abstract}
Ta članek naj bi prispeval k pojasnjevanju okoliščin in dejavnikov, ki vplivajo na inovativnost $v$ načrtovanju in graditvi stanovanj in $v$ urejanju prostora. Osredotoča se na vlogo Stanovanjskega sklada RS, ki pa je preveč zamejena, tako da sklad nima zakonskih podlag in sredstev, po nekaterih ocenah pa tudi ne ambicij, da bi uveljavljal svojo inovativno in razvojno vlogo. Njegova dejavnost se osredotoča na finančno-ekonomska vprašanja zagotavljanja neprofitnih stanovanj in stanovanj za trg. S programskega vidika pa je v ospredju zanimanje za njegovo pravno-organizacijsko obliko in za njegovo preoblikovanje v samostojno gospodarsko družbo. Ob strani pa ostaja široko področje družbeno-prostorskih sprememb, razvojnih usmeritev in vrednot $v$ kontekstu informacijske dobe (lizbonska strategija), ki terjajo inovativne sociološke, arhitekturne in urbanistične rešitve. Miselni vzorci, pravne norme in institucije pri nas zaostajajo za temi spremembami, tako da se stanovanje še naprej večinoma obravnava kot ločeni segment sam zase. Če naj bi ustanovanjski« skladi prevzemali naloge v novih razmerah, ki zahtevajo bolj celostno obravnavanje vsakdanjega življenjskega okolja ter reintegracijo bivanja, dela in rekreacije, potem že v zasnovi ne bodo mogli biti več le stanovanjski. Predstavljena je vrsta primerov inovativnih prizadevanj in njihovih zamejitev iz dosedanje prakse, obenem pa tudi zgledi in izkušnje v mednarodnem merilu.
\end{abstract}

KLUUČNE BESEDE: inovativnost, stanovanjski sklad, prostor, razvoj.

\section{Uvod}

Tako v mednarodnem merilu kot pri nas v Sloveniji se pojavljajo kritične ocene, da stanovanjska gradnja zaostaja za sodobnimi tehnološkimi pridobitvami in spremembami v načinu življenja v kontekstu informacijske družbe. To se izraža v manjši
This article attempts to contribute to clarification of the conditions and actors impacting innovativeness in housing construction and the management of space. It concentrates on the role of the Slovenian national Housing Fund, which is too restricted and lacks appropriate legal bases and means, and also-according to some evaluations - the aspiration to assert its innovative and developmental role. The Fund is focussed on the financial-economic aspects of providing non-profit housing and housing for the market. Currently attention is primarily directed towards its legal-organizational structure and its transformation into an independent company. This neglects broader consideration of socio-spatial change, developmental directions and values in the context of the information age (Lisbon Strategy), which call for innovative sociological, architectural and urbanistic solutions. Mindsets, legal norms and institutions in Slovenia are lagging behind these changes. Thus, housing is still mainly treated as a discrete segment. In order to perform their task in this new framework, which demands more integral treatment of the everyday living environment and reintegration of living, work and recreation, the mandate of the housing funds must no longer be confined merely to housing. Several examples of innovative design as well as their limitations are presented, together with examples of good international practice.

KEY WORDs: innovativeness, housing fund, space, development.

inovativnosti in številnih nejasnostih o tem, kako se bo spreminjala prostorska organizacija bivanja, dela in rekreacije $\mathrm{v}$ prihodnjih desetletjih. Čeprav se nakazujejo nekatere splošne usmeritve, kot npr. od enofunkcionalnih stanovanjskih naselij $\mathrm{k}$ integralnemu, vseživljenjskemu in ustvarjalnemu okolju, je praksa vendarle še močno drugačna. V iskanju 
vzrokov za take razlike in zaostajanje $\mathrm{v}$ uvajanju inovacij pa ni primerno, da se zamejujemo le na finančno-ekonomska vprašanja, temveč je treba kritično preučiti tudi prevladujoče miselne vzorce, ki obvladujejo dejavnost najvplivnejših akterjev.

Glede na navedeno bi morali preučiti celotno prostorsko-razvojno in stanovanjsko politiko ter vlogo posameznih akterjev, npr. več ministrstev. Tu pa se moram omejiti in bom poskušal konkretizirano predstaviti predvsem nekatera vprašanja in dileme o delovanju Stanovanjskega sklada RS. To delovanje pa je, kot bomo videli, že v izhodišču zelo omejujoče normativno opredeljeno. Kljub temu trenutnega stanja ne bi smeli sprejemati kot samoumevne danosti, saj lahko iz same prakse njegovega delovanja povzamemo tudi najbolj tehtne argumente za potrebno obogatitev njegove vloge in za bolj eksplicirano vsebino njegovega programa $\mathrm{v}$ povezavi $\mathrm{z}$ drugimi pomembnimi akterji stanovanjske politike in urejanja prostora. Še zlasti v socioloških obravnavah pa se ne moremo zaustaviti na ravni formalnih aktov in institucij kot apriornih danostih, ampak nujno vključujemo tudi tisto, kar je bolj prikrito, saj lahko npr. tudi vpliv posameznikov in njihove miselnosti znatno odpira ali zapira prostor za inovativnost.

\section{Nedomišljena izhodišča in normativne zamejitve}

\section{"Kdor ima ideje, se ne more prebiti do nas!"}

Stanovanjski sklad Republike Slovenije, javni sklad (v nadaljevanju: sklad), je ena od osrednjih institucij, ki vplivajo na širšo dostopnost stanovanj, vendar je njegova vloga kljub določenim razširitvam njegovih pristojnosti omejena in premalo opredeljena ter $\mathrm{v}$ zakonodaji določena kot izvajalska, in ne $\mathrm{z}$ vidika nosilca razvoja stanovanjske politike in drugih javnih politik. Na začetku njegovega delovanja ni bilo zunaj zakona določno opredeljene strategije; glavno je bilo le to, da se prejeti denar ${ }^{[1]}$ vloži v stanovanjsko gradnjo in da se gradi $\mathrm{v}$ javnem interesu. Tako je bil sklad najprej opredeljen kot finančni sklad, nato je vstopil tudi na področje gradnje in postal nepremičninski sklad. Poleg prvotne zamejitve na socialna ${ }^{[2]}$ in neprofitna stanovanja vključuje vse od leta 2001 tudi gradnjo stanovanj za trg. Temeljna usmeritev, ki jo uveljavlja na tem področju, je še vedno - zagotavljati ustrezno število stanovanj po dostopnih cenah!

Ob tem pa ostaja nedorečeno, kako sklad razvijati. Izkušnje kažejo, da je kot javni sklad preveč vezan na številna normativna določila, izhajajoča iz njego- vega statusa in narave, ter na javnopravne omejitve, tako da ne more delovati dovolj prožno (kot zasebni investitorji) in nima zakonskih podlag in sredstev za prevzemanje inovativne vloge. Glede na to tudi njegov direktor Primož Pirc pravi: »Kdor ima ideje, ki ne spadajo $v$ okvir naših dovoljenih dejavnosti, se ne more prebiti do nas! «

Mojca Štritof Brus, pomočnica direktorja, ki dobro pozna delovanje na tem področju tudi $\mathrm{v}$ drugih evropskih državah in kot pravnica sama uvaja inovativne rešitve v delo sklada, opozarja, da gre pri nas (torej na območju Slovenije) že v osnovi za napačno usmeritev: "Iščemo omejitve, in ne rešitev! "Vse je preveč togo, vnaprej določeno. Če npr. investitor konča delo pred rokom, skladno z javnopravno zakonodajo izplačilo nagrade $\mathrm{v}$ ta namen ne more biti dogovorjeno. V Veliki Britaniji, na Nizozemskem, v skandinavskih državah in drugod je takšno delovanje bolj sproščeno. Sklad pa je kot javni sklad omejen tudi v številu zaposlenih (določeno s kadrovskim načrtom Vlade Republike Slovenije) kot tudi v njihovem nagrajevanju in angažiranju zunanjih virov oziroma sodelavcev. Naročila so omejena s togimi predpisi o javnem naročanju. Zaradi javnega statusa je sklad omejen tudi pri kandidiranju za pridobitev sredstev, ki bi jih sicer lahko pridobil od Evropske unije. Z omejitvami se srečuje tudi pri dostopu do javnih evidenc, kjer je treba imeti zakonsko podlago (npr. Centralni register prebivalstva, Register stalnega prebivališča); vendar je nima.

Tako so zamejene samostojnost in možna inovativnost $\mathrm{v}$ tekočem delovanju sklada kot tudi njegova razvojna vloga $z$ vidika dolgoročnih usmeritev, ki bi presegale kratkoročne preokupacije politikov, ki so omejene na njihovo mandatno obdobje. Tu torej ni dosti razumevanja za razvojno problematiko, ki bi presegala okvire sprotnega, operativnega poslovanja, npr. v posebnem razvojnem oddelku, ki bi se osredotočal prav na takšno vsebino. Ozka uradniška miselnost in toga formalna določenost, izhajajoča iz statusa sklada, tudi za zaposlene postavlja meje izobraževanju in izpopolnjevanju nasploh.

Sicer pa je sklad samo primer splošne težnje k preveliki vnaprejšnji določenosti oziroma »reglementaciji«, ki v naši državi zamenjuje in izčrpava ustvarjalno energijo ljudi. V svetu je že znano, da so natančno načrtovana in regulirana okolja redko ustvarjalna.

Delovanje sklada je ujeto v začarani krog nerazjasnjenih razmerij med (ne)odgovornostjo, (ne) zaupanjem in (čezmerno) reglementacijo, ki naj bi preprečevala odmikanje od uresničevanja javnega interesa $\mathrm{v}$ Sloveniji nasploh in še zlasti v urejanju 
prostora. Na nedisciplino in pogoste kršitve predpisov (kakršnih ne poznajo na Nizozemskem in $\mathrm{v}$ skandinavskih državah) se poskuša država odzivati $\mathrm{s}$ še več predpisi, kar pa vodi do neživljenjskih omejitev in $s$ tem še okrepi težnje k novim kršitvam. Hkrati pa ljudje pri nas dostikrat ne obsojajo kršitev zakona, včasih pa celo štejejo, da gre za iznajdljivost sposobnega posameznika, pa naj gre za utajo davkov, črne gradnje ali prometne prekrške. Takšne kršitve bi bile nesprejemljive že po splošno sprejetih kulturnih normah nekaterih bolj razvitih in urejenih držav, pri nas pa so utemeljitev za omejevanje samostojnosti delujočih na tem področju.

Po drugi strani pa tradicija reševanja javnih zadev z vrha navzdol že a priori vključuje tudi nezaupanje do prebivalcev in drugih akterjev, ki so podrejeni oziroma odvisni od pristojnih državnih organov. Oboje skupaj pa je osnova za "prenormiranost «, ki na vsakem koraku - kot ugotavlja tudi Mojca Štritof Brus - togo zamejuje delovanje sklada.

Vse to je v ozadju in je vplivalo na nastanek sedanje pravno-organizacijske oblike sklada, ki je preveč toga in omejujoča ter jemlje preveč energije ljudi, namesto da bi jih spodbujala in sproščala v prožnejšem in ustvarjalnejšem reševanju "stanovanjskega vprašanja«. Zaradi negativnih posledic, ki jih ima za konkretno delovanje sklada, moramo torej posvetiti pozornost tudi tako široki temi, kot je prevladujoča miselnost v sferi upravljanja v naši državi nasploh. To, kar je veljalo že v prejšnjem političnem sistemu $^{[3]}$, se neopazno podaljšuje še zdaj. V mednarodnem merilu je znani avtor Charles Landry (1998) v svojem raziskovanju ustvarjalnega okolja opozoril na to, na kar sem podobno že pred leti opozarjal pri nas, namreč na negativni pomen miselnosti, ki se - sicer precej poenostavljeno - izraža tako: »Vse je prepovedano, razen če ni prav izrecno dovoljeno! Tisti, ki so prvenstveno privrženi ustvarjalnosti in inovativnosti, pa naj bi se bolj nagibali $\mathrm{k}$ temu, da je "vse dovoljeno, razen če ni prepovedano«. V zvezi s tem Jožka Hegler (2008), direktorica Javnega stanovanjskega sklada MOL, iz lastnih izkušenj ugotavlja, da je ogromno prepovedi oziroma neposrednih »zapovedi« za uporabo javnih sredstev, čeprav poskušajo delovati po načelu dovoljeno je vse, kar ni posebej prepovedano, kar vse ne le omejuje, temveč tudi destimulira inovativnost ${ }^{[4]}$. To povezuje $z$ dejstvom, da se reforma javne uprave $z$ ustanavljanjem agencij in skladov kot operativnejših oblik ni izšla, kot je bilo načrtovano. Zaradi premalo zaupanja $\mathrm{v}$ te institucije se jih je nenehno omejevalo. Pri tem poudarja moto, po katerem delujejo: "Tam, kjer je volja, se najde tudi pot. «Dodatno pa opozaria še na druga razmerja. Prepričana je, da je sinergijsko delovanje SSRS in lokalnih skladov ter občin potrebno in možno; državni sklad pa pobude po spremembi hitro vidi kot ogrožanje in zato proti lokalcem hitro (ali pa praviloma) nastopa $\mathrm{z}$ argumentom avtoritete in ne na način iskanja najboljših rešitev skozi konstruktivno partnerstvo.

Gre torej za nesamostojnost institucij (skladov) zaradi nezaupanja $» Z$ vrha navzdol«. Druga tema pa je nezaupanje do prebivalcev, ki kot posamezniki ne izkazujejo občutka odgovornosti za javni interes in potrebne discipline. Zaradi tega Gaberščik (2008: 2) ob problemu prenormiranosti hkrati izraža določene zadržke proti splošni liberalnosti:

$» V$ tem trenutku ne vidim možnosti še večje liberalizacije graditeljstva, nasprotno, nekje bi bilo treba zaostriti pogoje graditve, tam, kjer jih investitorji množično kršijo. Minimalni predpisi in standardi so potrebni povsod tam, kjer se vlagajo javna sredstva, zaradi racionalnosti in humanosti ... Kar zadeva same stanovanjske standarde velikosti, večsobnosti, opreme, ti izhajajo iz mednarodnih raziskav o minimalnem standardu za določeno številčnost družine. Zelo dvomim, da bi pri množični gradnji lahko gradili po meri. «

Vsaj za prihodnost pa zgledi dobrih praks iz razvitih držav nakazujejo možnost zbliževanja med posameznikom in sistemom: 1 . če bi se posamezniku bolj približali s "pomočjo za samopomoč« in ob tem zaostrovali tudi sankcioniranje nediscipline, in 2. če bi več pozornosti posvečali novim možnostim, da se na podlagi informacijsko-komunikacijske tehnologije povečuje udeležba prebivalcev v soustvarjanju njihovega grajenega in življenjskega okolja. ${ }^{[5]}$

Načela prihodnjega razvoja, še zlasti v javnem sektorju, naj bi usmerjala vse akterje (sklad) v prostoru tako, da bi bolj odpirali nove možnosti, bolj spodbujali in usmerjali, kot nadzirali in omejevali; bolj uveljavljali fleksibilnost $\mathrm{v}$ organizacijski strukturi ter vključevali specifično znanje, nove ideje in talente od drugod, kot pa podrejali in utrjevali klasično oblastno hierarhijo.

\section{Uvajanje novosti in iskanje usmeritev}

Ob vsem prej navedenem sklad vendarle uvaja nekatere novosti npr. $z$ vidika e-uprave in je kot novost začel razvijati celovit računalniški program (v sodelovanju $\mathrm{z}$ računalniškim podjetjem) za vodenje izvajanja svojih dejavnosti, ki mu bo sledil razvoj projektov. S pravnega vidika je sklad našel inovativne 
rešitve, npr. pri sklepanju pogodb in kombinaciji zavarovanj, ki v slovenskem prostoru niso zaživele ali jih ne poznamo v praksi. Opredelil je svoje produktne podlage in razvija parametre kakovosti po fazah gradnje s strokovnjaki, da bi zmanjšal »sivo cono« nedorečenosti vloge in pričakovanj investitorjev, prodajalcev, poslovnih partnerjev in kupcev. Še vedno pa ostaja primarno izvajalec stanovanjske politike države in deluje pretežno po javnem pooblastilu.

Pri tem se osredotočajo na spoznanje, da zamejena pozornost na najbolj ogrožene skupine prebivalstva ne rešuje nezadostne ponudbe stanovanj in s tem ne zbija tržne cene stanovanj in tudi ne višin profitne najemnine. Glede na to študija Ekonomskega inštituta Pravne fakultete v Ljubljani (Oplotnik, Križanič, Brezovnik, 2007) predlaga preoblikovanje javnega sklada SSRS v običajno gospodarsko družbo - nepremičninski sklad (N SKL, d. d.), vloga države pa bi bila omejena na socialne/ekološke korektive ter na reguliranje dejavnosti ${ }^{[6]}$.

Toda ob vsem tem ostajajo ob strani še temeljna prostorsko-sociološka, arhitekturna in urbanistična vprašanja o tem, kako se bo spreminjalo predmetno področje delovanja sklada, torej prav tisto, čemur je namenjeno. Kako se bo $\mathrm{v}$ prihodnosti spreminjal pomen stanovanja oziroma bivališča $\mathrm{v}$ kontekstu bivalnega, delovnega in vseživljenjskega okolja? Kakovost življenja čedalje bolj temelji na prepletanju bivalne funkcije $\mathrm{z}$ delovno, rekreacijsko, upravno in drugimi, ki jih ni več mogoče sektorsko izključevati. Vztrajanje pri obravnavanju stanovanja in bivanja samega zase bi že samodejno vodilo v vsebinsko osiromašenje in v odmikanje od dejanskih življenjskih razmer. Tudi če gre za posebno ciljno skupino, ki so ji namenjena neprofitna stanovanja, je potrebna prostorska, časovna in vsebinska razširitev obravnave.

Nekatere takšne vidike se sicer v praksi upošteva, vendar usmeritve niso jasno in sistematično opredeljene, npr. kolikšna je še dopustna koncentracija neprofitnih (socialnih) stanovanj na eni lokaciji oziroma kako zagotoviti, da bodo javni subjekti tudi v tržno opredeljeni stanovanjski gradnji vključevali določen (kolikšen?) delež takšnih stanovanj ${ }^{[7]}$. "Program sofinanciranja izgradnje neprofitnih najemnih stanovanj za leti 2008 in 2009" sicer vključuje zahtevo, da mora prosilec zagotoviti komunalno opremljeno zemljišče in da so zaželeni projekti, ki zagotavljajo tako neprofitna najemna stanovanja kot tudi stanovanja za prodajo na trgu.

Neposredno in posredno se širšim sociološkim, arhitekturnim in drugim vprašanjem, ki zadevajo prihodnost bivanja (npr. glede na povečevanje raznovrstnosti življenjskih slogov), približa opredelitev "produktov SSRS« (2006). Ta poleg pridobivanja komunalno opremljenih zemljišč, primernih za gradnjo stanovanjskih objektov in objektov mešane rabe, vključuje še pet kategorij stanovanj glede na njihovo namembnost izbranim ciljnim skupinam. ${ }^{[8]}$

S tem je podana določnejša opredelitev delovanja sklada, hkrati pa je očitno, da gre še za grobo členitev, ki kot izhodišče upošteva le starost, strukturo in dohodek tistih, ki se potegujejo za eno od stanovanj za trg. Šele v kategoriji »druga tržna stanovanja - z višjo ceno" so nakazane "različne opcije, ki se lahko posamično uporabijo in pomenijo višjo kvaliteto stanovanj (bodisi je to že sama lokacija bodisi gre za energetsko varčnejšo hišo ali inovativno - nestandardno arhitekturno zasnovo, nestandardno po velikosti)«. Pri tem gre za gradnjo stanovanj za zahtevnejše kupce, ki osnovo že imajo in si želijo npr. večje, lepše, modernejše stanovanje na boljši lokaciji ipd. Predlaganih možnosti pa (predvsem zaradi cene) ne bi mogli uporabiti hkrati, ampak bi jih upoštevali le posamično.

Šele pri zadnji kategoriji je nakazana možnost, da sklad investira $v$ inovativno arhitekturno zasnovo oz. v inovativne objekte, za kar naj bi lastniki tudi več plačali. Z večjimi sredstvi sta gotovo mogoča tudi več eksperimentiranja in večja individualizacija, vendar pa se iskanju inovativnih rešitev ni mogoče odpovedati tudi pri vseh drugih kategorijah stanovanj oziroma ciljnih skupinah bodočih stanovalcev, pri čemer pa se pojavi vprašanje financiranja ${ }^{[9]}$

Končno pa se samo tu (kategorija oz. produkt»druga tržna stanovanja z višjo ceno«) pri inovacijah pojavlja navezava na informatizacijo, ko se kot inovativne in nestandardne omenja tudi "pametne instalacije».

Zgrešeno bi bilo, če bi inovativnost uveljavljali in zamejevali le na novogradnje; saj ne gre za to, da bi novo kar frontalno ločevali od starega. Nove tehnologije, nove ekološke zahteve in nove vzorce prostorske organizacije je še dosti bolj zapleteno uveljaviti v prenovi stanovanj in stanovanjskih naselij. Na to je opozoril tudi B. Gaberščik, član nadzornega odbora sklada, ki je med drugim zapisal:

"Nič seveda nimam proti inovativni stanovanjski gradnji za bodočnost, vendar opozarjam, da vedno več ljudi stanuje $v$ sodobno prenovljenih starih hišah, ki imajo, kot se temu reče, tudi urbano dušo, in so z bivanjskimi pogoji prav zadovoljni. Brez dvoma moramo razširiti program stanovanjske gradnje, tudi zaradi novih zahtev po trajnostnem razvoju, torej prenovi določenih stanovanjskih četrti $v$ degradiranih mestih pa 
tudi zaradi zahtev po varčni rabi energije." (Gaberščik, 2008: 2).

Isti avtor pa je že dosti prej opozoril tudi na - lahko bi to označili kot sektorsko/disciplinarno - zamejitev, ki je bila vidna že v začetnem obdobju delovanja sklada, namreč da je bila dotedanja "politika SSRS ... zelo enostransko naravnana, predvsem 'ekonomistično', kar pa je nujno izhajalo že iz enostranskosti Stanovanjskega programa RS, ki ga je sprejel Državni zbor (in je bil slabši kot prvotni interdisciplinarni program iz 1. 1992) (Gaberščik, 2004). Takšna zamejitev pa nujno pomeni tudi zamejitev inovativnosti, ki je predmet tukajšnje obravnave.

\section{Inovativni predlogi: brez podpore?}

"Predlog programa SSRS za obdobje 2004-2008《 (Sklad, 2004) je vključeval še nekatere druge naloge, ki se ne omejujejo le na finančno sfero delovanja sklada in vključujejo tudi širši krog akterjev ter elemente prostorske organizacije bivalnega okolja. Tu sta najprej zagotavljanje ponudbe gradbenih parcel in partnerstvo z zasebnimi investitorji; nato spodbujanje gradnje v lastni režiji, ki je bila ocenjena kot pretežni način reševanja stanovanjskih problemov Slovencev - sicer ne racionalen, vendar realen. Nakazan je bil tudi Projekt rastoče hiše za mlade, tj. od minimalnih zasnov stanovanjskih enot in objektov h kasnejšim širitvam $\mathrm{z}$ najmanjšimi stroški. Sledi spodbujanje raznih oblik zadružništva. Bolj razčlenjeno je bil predstavljen Program dviga stanovanjske kulture. Poleg opredelitve minimalnih meril naj bi zagotovili tudi merila standardnih in nadstandardnih stanovanj, stanovanjskih objektov in stanovanjskih sosedstev. Za promocijo primerov dobre prakse v stanovanjski gradnji bi SSRS ustanovil ali spodbudil podeljevanje nagrad dobrim investitorjem, projektantom, graditeljem idr. Pri novih projektih bi iskali tudi inovativne rešitve, kjer bi z racionalnimi zasnovami objektov in stanovanj, sodobno tehnologijo in dodatnimi ukrepi za isto ceno pridobili večje površine stanovanj ali pa zaradi novih rešitev relativno znižali ceno za isto površino.

Inovativnost in upoštevanje trendov sprememb $\mathrm{v}$ prihodnosti, kar je moje osrednje zanimanje, se izrecno pojavlja v programu projektov Hiše prihodnosti, in sicer:

»SSRS bi v večji meri postal motivator inovacij in sodobnih rešitev na stanovanjskem področju. Kljub temu, da se je v zadnjem desetletju temeljito spremenil in se še spreminja življenjski slog ter posledično tudi način bivanja in dela ter $z$ njimi povezane stanovanjske potrebe, še vedno načrtujemo in gradimo stanovanja po starem. Taka zasnova jutri ne bo več uporabna, zato bi SSRS odprl program projektov Hiše prihodnosti in ga uveljavil tako v razvojnem smislu kot tudiv operativni tehnologiji in izvedbi. "(Sklad, 2004: 9, poudarki Z. M.).

Isti dokument je vključeval tudi projekt Svetovalne pisarne stanovanjske gradnje za lastne potrebe, $\mathrm{s}$ katerimi naj bi SSRS prispeval k izboljšanju načrtovanja in gradnje enostanovanjskih objektov v lastni režiji. Pri tem bi promovirali višjo stopnjo bivalne oz. stanovanjske kulture, informirali o sodobnih trendih načrtovanja, gradnje, rabe in vzdrževanja enostanovanjskega objekta, nakupa ali najema stanovanja in gradbenih parcel ipd.; spodbudili bi tudi pripravo priročnika za investitorje.

Ob tem je sklad naročal raziskave, kar bi bil lahko prvi korak k ustanovitvi posebnega razvojnega oddelka (o tem tudi J. Dekleva, 2008). Organiziral je simpozij Nove perspektive stanovanjske gradnje (27.-29. 10. 2003), razstavo Stanovanje za naše razmere (27. 10.-7. 11. 2003) idr.

Čeprav med prikazanimi elementi predlaganega programa in prikazanimi aktivnostmi vsaj izrecno ne najdemo izzivov, ki jih prinaša informacijska doba, je vendarle vseboval vrsto inovativnih pobud in veliko vsebinsko razširitev, ki presega statičnost pretežno finančne sfere in operativnega delovanja sklada. Niti takšna razširitev programa pa ni dobila potrebne podpore, ki bi zagotovila njegovo uresničevanje s podporo javnih politik s finančnimi in zakonskimi opredelitvami.

\section{Vsebinska obogatitev in razvojne perspektive}

Ob tem, ko že omenjena študija Ekonomskega inštituta pri Pravni fakulteti upravičeno poziva k večji samostojnosti in odprtosti sklada za javno-zasebno partnerstvo, pa hkrati pušča ob strani celoten kompleks vsebinskih usmeritev pri njegovem delovanju. Predložena sprememba pravno-organizacijske oblike je sicer lahko pogoj za vsebinsko obogatitev, vendar je sama po sebi še ne opredeljuje. Tudi če bi se sklad omejeval le na socialno vlogo, je ne bi mogel uspešno uveljavljati brez upoštevanja teženj drugih slojev prebivalstva (npr. težnje k segregaciji, »oplemenitenje - gentrifikacija starih mestnih jeder ipd.). Če pa že gre za poziv, da je treba upoštevati tudi druge kategorije stanovanj/stanovalcev, 
se tu odpira široko področje raznovrstnosti oziroma pluralizacije življenjskih slogov, ki daleč presega nekaj že uveljavljenih kategorij, kot so stanovanja za mlade (družine), ostarele, telesno in/ali duševno motene ipd. Te raznovrstnosti pa tudi v prihodnje ne bo mogoče zajeti ob pristopanju »z vrha navzdol«, ampak predvsem tako, da bi povečevali možnosti za individualizacijo in aktivno vlogo potencialnih uporabnikov v snovanju in graditvi bivalnega okolja. Za to pa se že odpirajo nove možnosti z informacijsko komunikacijsko tehnologijo, ki omogoča načrtovanje in graditev stanovanj "po meri« za posameznika in celo za množico posameznikov, kot to nakazuje v svetu že uveljavljeni izraz "mass customisation" (gl. tudi Dekleva in dr., 2002). Vendar to doslej pri nas v praksi ni bilo upoštevano kot izhodišče in usmeritev za stanovanjsko gradnjo.

Nakazano pa zahteva, da sklad (pre)usmeri svojo pozornost od samoumevnega podaljševanja dosedanjega delovanja in usmeritve na nekatere vnaprej določene kategorije uporabnikov na inovativna prizadevanja in rešitve v mednarodnem merilu. Korak v tej smeri je bila pred leti skladova podpora evropski organizaciji Europan, ki prireja natečaje na izbrane arhitekturne in urbanistične teme, na katere se s svojimi prispevki in dostikrat izvirnimi rešitvami (pri nas na natečaj Izole, Maribora, Brežic in Ljubljane) odzivajo mladi arhitekti iz evropskih držav. Vendar je tudi ta podpora sklada - usahnila!?

V njegovem prihodnjem delovanju bi lahko okrepili njegovo vlogo kot enega od pomembnih dejavnikov v kontekstu razvojnih prizadevanj slovenske družbe. To pa predpostavlja predpostavlja stanovanjsko politiko, ki v stanovanju ne vidi le možnosti nastanitve ljudi (nekakšen mrtev kapital), ampak tudi sredstvo za prednostno uveljavljanje določenih razvojnih programov, še zlasti z vidika vključevanja v družbo znanja. To je le fragmentarno opazno v tem, da se med prednostne kategorije kupcev v javnih razpisih sklada uvršča mlade raziskovalce in asistente stažiste. Vendar gre še za vrsto drugih možnosti. Nerazjasnjene in premalo upoštevane ostajajo tudi razsežnosti prostorske organizacije in lokacije stanovanjske gradnje ${ }^{[10]}$. Tu je še preveč naključnosti in premalo izdelanih usmeritev, ki bi krepile celostnejšo obravnavo posameznih lokacij, kot bi bilo treba pri ločenem načrtovanju stanovanjskega naselja in Tehnološkega parka $\mathrm{v}$ Ljubljani na Brdu. Čeprav se navaja, da bo ta nekakšno mesto v malem, gre na območju Brda vendarle za to, da sta zasnovana dva ločena programa: osrednjo pozornost se posveča tehnološko-poslovnemu segmentu, ki naj bi bil obogaten $\mathrm{z}$ najnujnejšimi storitvami za zaposlene; ločeno od tega pa je zasnovana stanovanjska poselitev s 650 stanovanji skoraj brez javnega programa. Pri tem pa ni bila opredeljena sinergija med enim in drugim. To pa se ni zgodilo naključno, temveč je - med drugim - logična posledica »sektorske zadolženosti« sklada, ki nima pooblastila za javni program, zato niti ne more opravljati integrativne vloge $\mathrm{v}$ razvojni perspektivi od monofunkcionalnih, stanovanjskih naselij k bolj raznovrstnemu, vseživljenjskemu okolju. Prav takšno pa je okolje, ki ga želimo ustvarjati zato, da bi bilo spodbudno za ustvarjalnost.

Ne gre torej le za število stanovanj, ampak tudi za razvojne učinke glede na kontekst, $\mathrm{v}$ katerega se bolj ali manj - vključujejo. To velja tudi za lokacijo stanovanj za študente oziroma lokacijo študentskih domov, pri čemer povsem prevladuje naključna razpoložljivost lokacij. Poseben izziv so nova univerzitetna središča, ki že praviloma nastajajo brez potrebne stanovanjske infrastrukture, čeprav naj bi bila nekakšna jedra ustvarjalnosti in (regionalnega) razvoja.

Že v prejšnjih letih je bilo poudarjeno, da bo sklad gradil stanovanja, ki bodo vzor za gradnjo drugim investitorjem: pri vseh projektih bodo pozorni na okoljsko sprejemljivost objektov, energetsko varčnost, inovativnost pri rabi gradbenih materialov, kakovost umeščanja $\mathrm{v}$ prostor in dobre arhitekturne rešitve. S projektom vzorčne stanovanjske hiše naj bi odpravili dvajsetletni zaostanek slovenske stanovanjske arhitekture. Ob vsem tem pa - mogoče tudi zaradi prevladovanja pozornosti fizičnim razsežnostim grajenega okolja, ki so v ospredju preokupacije arhitektov - ne najdemo sledu o tem, kako upoštevati velike spremembe, ki jih prinaša informacijska tehnologija; kot da celotno delovanje ostaja $\mathrm{v}$ predinformacijski dobi!? Nerazdelana so vprašanja, kako pri snovanju prostorske organizacije grajenega okolja, ki bo dolgotrajnega značaja, že zdaj anticipativno upoštevati čedalje večji pomen inteligentnega okolja ter reintegracijo dela in bivanja ipd. Informatizacija $\mathrm{z}$ vsemi pridobitvami, ki jih sicer prinaša, ostaja premalo izkoriščena $v$ dejavnostih, ki zadevajo stanovanjsko načrtovanje in udeležbo prebivalcev kot tudi graditev stanovanj ter njihovo rabo in kakovost bivanja. Pri tem je še veliko nejasnosti tudi $\mathrm{v}$ mednarodnem merilu; pomembna pa je privrženost iskanju inovativnih rešitev v svetu in preverjanju možnosti za njihovo uporabo v naših razmerah. Ob vseh številnih splošnih deklaracijah o tem pa Ministrstvo za okolje in prostor s svojim delovanjem kaže bolj na svojo samozadostnost kot pa na vrednotenje strokovnosti, s katero bi lahko uveljavljali inovativne razvojne programe stanovanjske gradnje.

Glede na to, da se, kot ugotavljajo v svetu, inovacije v stanovanjski gradnji pojavljajo pretežno v velikih 
stanovanjskih združenjih, pa bi si moral v Sloveniji vendarle prav Stanovanjski sklad Republike Slovenije, javni sklad, prizadevati, da bi lahko načrtno uveljavljal svojo inovativno vlogo, kar bi morala spodbujati in razvijati ter seveda finančno podpirati tudi država.

\section{Sklep}

Inovativnost $\mathrm{v}$ stanovanjski gradnji $\mathrm{v}$ Sloveniji je sestavina širšega kompleksa družbeno-prostorskih sprememb, ki je predmet razvojne, prostorske in stanovanjske politike. Te jo večinoma tudi določajo. Z okvirnimi določilnicami in $\mathrm{v}$ kontekstu informacijske dobe sem poskušal osvetliti, kakšna je in kakšna naj bi bila vloga SSRS. V nacionalno-državnem merilu je bolj poudarjena restriktivno-represivna vloga državnih organov kot pa spodbujanje in usmerjanje $\mathrm{k}$ ustvarjalnosti in inovacijam $\mathrm{v}$ načrtovanju in graditvi stanovanj in $\mathrm{v}$ urejanju prostora z vidika sprememb, ki prihajajo. To je po eni strani odziv na pomanjkanje discipline in odgovornosti prebivalcev, precej pa tudi znak apriornega nezaupanja in inercije politične prakse iz preteklosti. $\mathrm{V}$ tako zamejenih okvirih in ob sedanjem drobnooperativnem delovanju pa bo sklad vendarle moral upoštevati tudi širši časovni in vsebinski kontekst s poudarjeno usmeritvijo v dolgoročnejšo prihodnost. Po eni strani potrebuje večjo samostojnost, ki bi mu omogočala vsebinsko obogatitev delovanja tudi $\mathrm{z}$ dosedanjimi zamejitvami na finančno-ekonomsko sfero, in večje upoštevanje sprememb ter raznovrstnosti v načinu bivanja in življenja ljudi, hkrati s pritegovanjem nedržavnih virov. Tu bi morali najti prostor za inovativno iskanje tako $\mathrm{z}$ vidika načrtovanja kot graditve in prenove stanovanj $\mathrm{z}$ novimi načini vključevanja in soudeležbe uporabnikov. Po drugi strani pa naj vloga sklada vendarle ne bi bila izenačena z (drugimi) razvojniki na tržišču. Glede na čedalje vidnejše negativne izkušnje ob izrivanju javnega interesa (kot so nehumane zgostitve v omejenih prostorih) potrebujemo akterja, ki bo vstopal v partnerske odnose $z$ drugimi na trgu, hkrati pa bo presegal ozke interese tako z razvojnimi inovacijami kot s svojo korektivno vlogo.

Dr. Zdravko Mlinar, univ. dipl. prav., akademik, zaslužni profesor E-pošta: zdravko.mlinar@fdv.uni-lj.si

\footnotetext{
Zahvala

Zahvaljujem se vsem citiranim in drugim strokovnjakom, s katerimi sem opravil pogovore in ki so mi posredovali svoje dragocene izkušnje za pripravo tega besedila.
}

\section{Opombe}

[1] Denar $v$ danem primeru pomeni vire za zagotovitev zagona poslovanja skladno z ustanovitvenimi akti.

[2] Termin socialna stanovanja $\vee$ stanovanjski zakonodaji ni več opredeljen.

[3] $\vee$ zvezi s tem smo sociologi kritično opozarjali na nevzdržno normativno zamejevanje in na »normativni idealizem«, ki predpostavlja, da je predvsem s pravnimi sredstvi mogoče reševati družbene probleme.

[4] Poleg tega pa še pogosto spreminjanje prostorske zakonodaje »povzroča zmešnjavo« (o tem Jana Gojanović Purger in drugi v razpravah $\vee$ Zbornici za arhitekturo in prostor, 2008) in izčrpava ustvarjalno energijo strokovnjakov in prebivalcev nasploh.

[5] Prav v zadnjem času se uveljavlja »mass customization « kot množična individualizacija na podlagi interneta in avtomatizacije v proizvodnji avtomobilov in računalnikov, nakazuje pa se tudi $v$ načrtovanju in graditvi stanovanj.

[6] Ob tem Jože Dekleva (2008) dodaja: »Ne izključujem možnosti, da sklad vizrednih razmerah - previsoke cene - poveča ponudbo stanovanj in tako zmanjša negativne učinke gradbenega kartela, vendar osrednja vloga sklada ostaja zadovoljevanje stanovanjskih potreb dohodkovno šibkejših skupin ... Na potrebe [zahtevnejših kupcev] bo odgovoril trg, če bo država zagotovila pogoje za konkurenco med ponudniki.«

[7] Npr. v Haagu mora razvojnik na lokaciji za novo stanovanjsko gradnjo zagotoviti 30 odstotkov neprofitnih stanovanj (J. Dekleva, 2008). $\checkmark$ univerzitetnem mestu Amherst, ZDA, s 35.000 prebivalci imajo zelo natančno določene deleže »dostopnih« (affordable) stanovanj po velikostnih razredih zaselkov, seveda pa ob povsem prevladujoči tržni gradnji.

[8] Gre za najemna stanovanja (neprofitna najemna in varovana ali oskrbovana) in za tržna stanovanja (za mlade družine in še nekatere prednostne kategorije, tržna z višjo ceno, ki je nižja od tržne, in spet za varovana ali oskrbovana stanovanja).

[9] Iz intervjujev s poznavalci te tematike ugotavljam, da gre za različne poglede na možnosti za inovativnost na področju socialnih oziroma neprofitnih stanovanj: nekateri vidijo tu večje omejitve, drugi pa še večjo potrebo po inovacijah.

[10] V dokumentu Produkti SSRS (6. 6. 2006) so nakazane določene smernice lokacije tržnih stanovanj za mlade družine. Ta naj bi sklad »gradil ali kupoval v nacionalnih središčih, njihovi neposredni bližini in regionalnih središčih, tam, kjer je potreba po tržnih stanovanjih in kjer so cene stanovanj najvišje in zato tudi najmanj dostopne mladim družinam«.

\section{Viri in literatura}

Dekleva, A., Gato, M., Gregorič, T., Sedlak, R., in Stroumpakos V. (RAMTV) (2002) Negotiate my Boundary! London. AA Publications.

Dekleva, J. (2008) Osebna komunikacija (19. 3. 2008)

Gaberščik, B. (2008) Mnenje k eseju Zdravka Mlinarja o inovativnosti v stanovanjski gradnji in vlogi Stanovanjskega sklada RS. Ljubljana. Tipkopis.

Gaberščik, B. (2008) Komentar. Trajekt. Dostopno na: http://www.trajekt. net/?id=237\&tid=9 (sneto 16. 7. 2004)

Hegler, J. (2008) Osebna komunikacija (22. 4. 2008).

Landry, C. (1998) Helsinki: Towards a Creative City. Helsinki. Urban Facts.

Oplotnik, Ž., Križanič, F. in Brezovnik, B. (2007) Možnosti za izboljšanje vpliva nacionalnega stanovanjskega sklada na slovenski nepremičninski trg. Gospodarska gibanja, 396, str. 24-47.

Mlinar, Z. (2007) Informacijske, normativne in fizične osnove urejanja prostora. Geodetski vestnik, 51(2), str. 276-292.

Mlinar, Z. (2008) Informatizacija, upravljanje in inovativnost $v$ vsakdanjem življenjskem okolju. Teorija in praksa, 45(1-2), str. 5-27.

Novak, J. (2004) Predlog programa SSRS za obdobje 2004-2008. Dostopno na: http://www.trajekt.net/?id=237\&tid=9 (sneto 16. 7. 2004). 